\title{
WHO cares: a history of light and shadows
}

\author{
Marcos Cueto, Theodore M. Brown and Elizabeth Fee: The World \\ Health Organization. A history. Cambridge: Cambridge University \\ Press, 2019, xvi + 373 pp, 32.76€ PB
}

\section{María-Isabel Porras-Gallo ${ }^{1}$}

Accepted: 5 August 2021 / Published online: 11 August 2021

(c) The Author(s), under exclusive licence to Springer Nature B.V. 2021

The current pandemic has given greater relevance to the concept of Global Health, to the World Health Organization (WHO) and to this book, which is the result of important research and brilliant reflections by three well-known historians working over a period of nearly two decades. This collaboration has already produced noteworthy papers, books and chapters that have contributed to the development and maturity of part of the content of this volume on the history of the WHO. The result is an outstanding and innovative book, clearly worthy of being published in the collection 'Global Health Histories,' edited by Sanjoy Bhattacharya. Sadly, Elizabeth Fee passed away on October 17, 2018, before the book was published.

The judicious selection and use of numerous and varied primary sources (including a large quantity of significant documents from the most important European and United States archives, as well as oral testimonies from Ilona Kickbusch and Halfdan Mahler, key WHO figures with different responsibilities), combined with an outstanding and up-to-date secondary bibliography, contribute to offer a very different history of the WHO, through its eleven chapters plus introduction, bibliography, and a very helpful index. This study, unlike previous ones (official and semi-official) about the WHO is, as the authors state in the introduction, "a narrative history" and "a synthetic overview and assessment of how consistently and how well the WHO has pursued" (1) the mission of the WHO, namely "the attainment by all peoples of the highest possible level of health," as stated in the Constitution of the international agency. Reading the pages of this admirable book allows us not only to approach the history, actions and interactions among the main actors- the leaders, health policymakers, physicians, and scientists—of the first seventy years of the WHO, but also to observe the consequences of the different paths of the WHO's activity in the

María-Isabel Porras-Gallo

mariaisabel.porras@uclm.es

1 Faculty of Medicine, Ciudad Real, University of Castilla-La Mancha, Camino de Moledores, s/n. 13071, Ciudad Real, Spain 
evolution of the health problems and quality of life of the world population, as well as to better understand our current pandemic situation and reactions to it.

Throughout the first five chapters of the monograph, entitled "The Making of an International Health Establishment" (Chapter one), "The Birth of the WHO 1945-1948" (Chapter two), "The Start-Up Years, 1948-1955" (Chapter three), "The Cold War and Eradication" (Chapter four) and "Overcoming the Warming of the Cold War: Smallpox Eradication" (Chapter five), we can see how the WHO became "the acknowledged international leader on matters of health and disease" and played "a pre-eminent role in the political validation of international health as a field" (1). Its central position in the network integrated by experts (physicians and other scientists), health policymakers, and diplomats enabled it to establish technical assistance for developing countries, which was also a key element for the reconstruction and modernization of the Spanish research (virology, epidemiology, etc.) and health care system during the Franco dictatorship, as the recent publications of Spanish researchers have shown (Ballester, 2016; Rodríguez-Ocaña and Ballester, 2019; Porras and Báguena, 2020a, b).

Chapter six, entitled "The Transition from 'Family Planning' to 'Sexual and Reproductive Rights", and Chapter seven, "The Vicissitudes of Primary Health Care," show the transition between the WHO's position of its early decades to its new situation, marked by accusations of irrelevance, inefficiency and lack of transparency at the end of the 1980s. This period coincided with the rising importance of neoliberalism, among other important political changes in the world, and the transformation from international health to global health. The effects are very clearly presented in part of chapters six and seven, and particularly in the last four chapters "The response to the HIV/AIDS Pandemic" (Chapter eight), "An Embattled Director-General and the Persistence of the WHO" (Chapter nine), "The Competitive World of Global Health" (Chapter ten) and "The WHO in the Second Decade of the 21st Century" (Chapter eleven). The serious questioning of the WHO's authority in the coordination of international health has had a significant effect on the role played by the WHO in recent decades, and on its activities regarding the effective generalized introduction of birth control and the vital project of primary health care, whose important role has been and continues to be confirmed by the current COVID-19 pandemic. This unfortunate experience once again highlights the two different perspectives - the socio-medical, and the technocratic-biomedical-in the various programs of the WHO, reflecting the orientation of the organization itself, as this book shows. An example is the role given to immunization in solving the current health crisis, a technique also seen as a contentious substitute for the generalized establishment of primary health care (183-193).

Chapter eight describes the initial inaction of the WHO when confronted with the HIV/AIDS pandemic; its key role starting in 1986, a position lost in the 1990s, before the organization's recovery of its leadership in this area in the twenty-first century. This history reflects the international agency's change of orientation and its progressive dependence for its finance on private organizations, which have constrained some of its activities in the health field. This situation and the WHO's shared leadership with the World Bank from the 1990s onward is analyzed in chapter nine, which highlights the role played by its successive 
(and often criticized) General Directors from the end of the 1980s until the end of the first decade of the twenty-first century. From the public health perspective, this period was marked by the changes carried out in the WHO not only in response to the emergence and re-emergence of infectious diseases (Avian flu 1997, SARS 2003, influenza pandemic 2009-2010, among others), but also by its activity against the problem of the use of tobacco. A good example is the final part of chapter ten, dealing with the election and work of Margaret Chan. She was chosen because she had experience in the management of bird flu and SARS 2003, and because her origins might be able to promote relations between the WHO and China, and thereby encourage China's compliance with global health rules. However, as the authors note, this strategy proved unsuccessful and Chan's management of the 2009 health crisis was unpopular.

The final chapter deals with the new challenge that the WHO faced with the appearance of the Ebola epidemic in Africa, initially underestimated by the agency, and how this episode revealed not only the WHO's problems in playing a coordinating role in the global response to this epidemic, but also the difficulties it faced in maintaining its legitimacy as an international health agency. The authors detail the search for new solutions that would make it possible to tackle the sanitary problem and the current challenges of global health, as well as to recuperate the institutional authority of the international agency. This concluded with the election of the new director general of the WHO from Africa, the Ethiopian Tedros Adhanom Ghebreyesus.

To conclude, I think the authors are to be congratulated, not only for presenting us with this splendid, up-to-date and excellently contextualized history of the WHO, which constitutes a reference work about this international agency; but also for inviting us to engage in a historical reflection, and for drawing lessons from this history to be applied to the present and future of the mission of the WHO, as they do in the last section, "Looking to the Past; Looking Ahead" (335-340). So we should take advantage of this book, and the opportunity afforded by the current COVID-19 pandemic, to recover the values of the multilateral health agencies and collective, free and open cooperation between nations "to make these health and social rights realities and promote health" (340) in all the countries of the world, so that a holistic view of health can prevail, and sociomedical measures can be combined with biomedical means.

\section{References}

Ballester, Rosa. 2016. España y la Organización Mundial de la Salud en el contexto de la historia de la salud pública internacional (1948-1975). Valencia: Real Academia de Medicina de la Comunidad Valenciana.

Porras, María-Isabel., and María-José. Báguena. 2020a. The role of the World Health Organization country programs in the development of virology in Spain, 1951-1975. História Ciências SaúdeManguinhos 27 (suppl 1): 187-210. https://doi.org/10.1590/S0104-59702020000300010. 
Porras, María-Isabel., and María-José. Báguena. 2020b. El papel desempeñado por los médicos, el gobierno y la OMS en la implementación de las encuestas serológicas sobre polio, sarampión y rubeola en España (1958-1978). Asclepio 72 (1): 295. https://doi.org/10.3989/asclepio.2020.04.

Rodríguez-Ocaña, Esteban, and Rosa Ballester Añón. 2019. El informe del consultor de la OMS Fraser Brockington de 1967, en el contexto del reformismo sanitario franquista. Dynamis 39 (2): 477-496.

Publisher's Note Springer Nature remains neutral with regard to jurisdictional claims in published maps and institutional affiliations. 